\title{
THE DISCONNECTED VOICES OF MOTHERHOOD AND DAUGHTERHOOD IN TONI MORRISON'S PARADISE: JOURNEY FROM UNCERTAINTY TO CHAOS
}

\author{
Ahdiyeh Alipour ${ }^{1}$, Zanyar Kareem Abdul ${ }^{2}$ \\ ${ }^{1}$ Department of English, University of Applied Science and Technology, Iran \\ ${ }^{2}$ Department of English, College of Education, University of Charmo, Iraq \\ E-mail: aa_1210@yahoo.com
}

Received: 20 June 2020

Accepted: 06 October 2020

\begin{abstract}
This paper is an attempt of analysing the problematic mother-daughter relationship in Paradise (1998), a female coming-of-age novel by Toni Morrison. In the novel, a black woman and her daughter had an uneasy relationship. The daughter strived to shape her own identity and future, but her uneasy relationship with her mother profoundly affected her choices and the way she lived. Undoubtedly, the patriarchal environment that had moulded the female identity and shaped a woman's world resulted in a dysfunctional relationship between mother and daughter. Although the seed of maternal love existed in her heart as in all mothers, she was often incapable of transferring this love into words and actions, overwhelmed as she was by the pressures patriarchal society. The oppressive pressure on black women is depicted far surpassed that on the whites, and the former were ostracized from society merely because of who they were and by the colour of their skin. This paper explores how patriarchy and conventional beliefs could influence the mother-daughter relationship and prevented the expression of a mother's true love, consequently depriving them of the opportunity or ability to perform physiologically and psychologically as mothers, biological or otherwise, in black communities. To liberate herself, the daughter had to struggle in the swamp, which her ancestors had created by the force of convention and patriarchy. However, when she eventually discovered the way to free herself from the swamp, she felt no welcome from society and so continued to remain isolated and ostracised.
\end{abstract}

Keywords: patriarchal society, relationship, choices, swamp, ostracised, black communities.

\section{Introduction}

Morrison insisted on calling this novel War initially, but several publishers were concerned that this title would repel readers, so in spite of her doubts, she named her seventh novel Paradise.

Paradise is set in a small town in Oklahoma and attempts to reveal the fact that history and past events are closely connected in establishing the present and future of a community. This study presents an overview of African-American history, not unlike Morrison's former works. The story evolves from the African-American history of slaves and their ancestors in the $19^{\text {th }}$ century, and how they escape from the widespread cruelty of racism in the South. 
The Disconnected Voices of Motherhood and Daughterhood in Toni Morrison's Paradise: Journey from Uncertainty to Chaos, Ahdiyeh Alipour, Zanyar Kareem Abdul

Some former slaves from the South attempt to escape the bonds of slavery and relocate to a smaller place in search of freedom and hope, lured by the promise of recruitment campaigns and land incentives.

Morrison incorporates in Paradise, the north-western departure of African Americans in the US mythic history of westward migration. The town of Ruby is depicted as a haven for these coloured people who were forced to escape the pain and torture they experienced at the hands of the light-skinned people of Oklahoma, an event known as the Disallowing, in addition to the economic and political exclusions imposed upon them by the white people. The issues that arise in the all black towns of Oklahoma and Kansas culminate in these westward migrations. Two of these all black towns were Morrison's motivation for Paradise. One of them is Boley in Oklahoma, a town with 4000 residents, where not even a single arrest had been observed for many years, and which brings to mind images about Haven and Ruby in Paradise's primary chapter as being crime free: "It neither had nor needed a jail". Another town was Langston City, also in Oklahoma, which published its own local paper and where all residents were urged to do their share of work as responsible citizens in order to succeed. The American West's significant virtues of its people were independence and pride. None of the townsfolk were allowed to dwell on the many unfortunate and destitute events, chiefly because failures were not accepted among the all black societies of the West. Therefore, they are resolute in upholding these principles and warn newcomers and black immigrants from the West to" Come Prepared or Not at All." The characters in Paradise are extremely frightened by this sign that appears on their way to Haven. Morrison mentions both Boley and Langston City in this work since these towns had to bear several burdens and shocking events. In Paradise, Morrison tells the story of how these coloured settlers tolerate hardship and torture in the imaginary town of Ruby.

In African American history, slavery is the most indelible stain in black people's lives, causing much pain and suffering, humiliation and bloodshed that leaves them with a lifetime of trauma. When slavery was abolished, thousands of black people fled from the north to south in search of new opportunities for a better economic future, and freedom to gain control over their own destinies.

Toni Morrison created her masterpiece, Paradise, based totally on African American history; it depicts the different issues confronting these communities. In Toni Morrison's trilogy of novels, Beloved, Jazz, and Paradise, she repeats this theme with a different storyline each time to create multiple versions of stories, which demonstrate the process of healing, change, and insight. In Paradise, Morrison depicts the volatile relationship between race and gender. She portrays racial abuse which is connected to gender, class and sexual relations, and utilises contemporary feminist, black, and postmodern theories of representation in her book. Morrison, as an African American feminist, examines the lives of blacks especially black women who have lived in America.

The problematic relationship between two communities, the small towns of Ruby and Oklahoma, and a very small but extremely independent group of women, who live in a Convent located in the suburb of Ruby, form the basis of this novel. The town's communal spirit is challenged, and in a desperate search for a solution, the people blame the convent women for this threat. These women are portrayed as unfortunate victims who silently suffer oppression by the dominant men of Ruby; these women are abandoned and deemed incapable of rehabilitating their shattered homes and lives.

Paradise is a combination of complicated characters who navigate life amid turmoil and struggle. The novel highlights the efforts made to protect Ruby from destructive elements. In 
the first chapter, several men from Ruby attack the defenceless women who live in a mansion, called 'the Convent'. The attackers believe this is the best solution towards protecting their lifestyle. To the reader, this onslaught on women cannot be justified because they are not seen as a threat. The reader is gradually provided with detailed information about the characters of the people in Ruby, and the women of the Convent. The story moves forward in time, but the omniscient voice provides the narrative of the story through different aspects of the characters' past memories. The reader is able to unfold the history of the town, its development, the secrets of the townsmen and their vicious attitudes towards women. Ruby was founded in 1950 by a group of African Americans who had fought in World War II. Ruby was built out of the ruins of another town, Haven, which was founded in 1890 by black settlers from Mississippi and Louisiana, i.e., the ancestors of the people of Ruby. Many of those early settlers held jobs and high social positions, but a racist society forced them to leave their jobs and everything behind and move elsewhere to create a prosperous future. These black immigrants suffered from several misfortunes and hardships. Most of Ruby's residents used to live in Haven, which was a wealthy and thriving town from 1890 to 1940 before it lost its affluence. There was an old building, a few miles from Ruby, which was called The Convent because it used to be a Catholic school, but when the nuns left, this mansion told a different story.

Connie is one of several women who had lived most of her life with the nuns at the convent, which also served as a shelter for women. These women comprised an unfortunate wife and mother who had been harassed by her own family; a young woman attempting to reform her life independent of other people's dictated standards of morality and two young women whose lives have been uprooted by several misfortunes. The impartial and welcoming environment of the Convent was paradise to them, but living nearby to Ruby's fanatical people brought numerous conflicts, which ended in bloodshed. The noticeable message of this novel could be that paradise cannot be achieved without any struggles and endeavours. This story is a challenging historical novel encompassing family genealogy and mysticism, which evokes different interpretations and responses from readers. The reader is able to feel the torment and suffering of women inflicted by men of society, who steadfastly hold on to traditional and extremist beliefs which wreak havoc.

This complicated storyline slowly unravels and gains clarity in the final chapters the reader is encouraged to read this work because it is challenging, due in part to Morrison's non-chronological technique of writing. In addition, the reader is forced to work through the novel to discover the truth, not unlike piecing together different pieces of a puzzle.

\section{Literature Review}

The significant role of mothers in family and society has been a favourite subject of many remarkable writers, and the most eminent of African American writers who consistently writes around the theme of motherhood is undeniably Toni Morrison. Andrea O' Reilly in her book "Toni Morrison and Motherhood: A politics of the heart" examines all of Morrison's works, which depict African American women's experiences, a subject ignored by white feminism. She states that politics of the heart, expounds an African American theory that expresses the coloured women's fight against racism, sexism, and suppression in a patriarchal society. She scrutinizes the historical differences in motherhood between white women and enslaved ones in the 19th century, and notes that the Industrial Revolution inspired the belief of 'True Womanhood', which reflected passivity, virginity and virtue; qualities that inevitably led to the oppression of women. However, Morrison does not 
The Disconnected Voices of Motherhood and Daughterhood in Toni Morrison's Paradise: Journey from Uncertainty to Chaos, Ahdiyeh Alipour, Zanyar Kareem Abdul

represent, in her writings, a fixed portrayal of the black 'mammy', which, traditionally, conjures up a picture of the black woman as refugee, and whites as arrogant slave masters who treat black women as inferior beings. Morrison focuses on the black women's ability to nurture her offspring although working in a cruel and exploitative society. In addition, Bakerman (2013) in her article "Failure of love: female initial in the Novels of Toni Morrison" states that whereas all the female characters in Morrison's novels are seeking love, sexual gratification etc., the most significant ones seek a sense of genuine values. She continues that Morrison's initial works speak of the black women's real values, these values had been assigned only to middle-class whites, hence the values of black women change because of restrictions imposed by men who attempt to control them. She declares that female inspiration for rebellion is a joke, because it cannot justify a better world for them; their fate lies in marriage and motherhood because there is no way out for them. Either way, their life only offers tragic consequences for themselves and others. Generally, there are several interpretations about the meaning and role of motherhood, and these themes are dealt with in various literary works. Ross (2013) also studies this theme in recent history in her article "New thoughts on The Oldest Vocation: Mothers and Motherhood in Recent Feminist scholarship". She scrutinizes the role of mothers by studying their daily activities that revolve around their children and how they emote in circumstances that challenge their parenting abilities. Parenting can have different connotations. She proclaims that motherhood is challenging because it is fraught with a whole range of feelings and frustrations; it has its high and low points and more so the latter, especially where a woman has to deal with criticism and hostility. Adams (2013) in her article "Maternal Bonds: Recent Literature on Mothering" believes black mothers, poor mothers, single mothers, lesbian mothers, or generally all mothers, who are not defined in terms of norm as middle class and white mothers, are psychologically and socially dangerous. Consequently, feminists have to theorize mothering in their works. She states that mothers are the main foundations of anxiety and emotional pain for their children, particularly for their daughters. Daughters in the society are forced to reject their mothers' role in order to become free, but this way they will be called rebels. They also imitate their mothers' role as an obedient housewife who is depended on men and lacks self-esteem. However, black women's perception is somehow different from European notions based on Chaney's article (2013) "The character of womanhood: How African American women's perceptions of womanhood influence marriage and motherhood". She asserts that the meaning of womanhood in an African American family structure and their experiences are tremendously different from that of white women. She believes African American women define a new meaning of womanhood with regard to their own social class and economic status in their black community as well as in relation to black men. Consequently, their perspective on marriage and motherhood is highly different.

Paradise is an eminent novel of Morrison that numerous women have studied and worked on for it depicts the courageous efforts of black women to achieve their rights under an oppressive society. Mayberry (2013) in "Everything about Her Had Two Sides to It: The Foreigner's Home in Toni Morrison's Paradise "expresses a critical analysis about the relations between host and home of the female heroes in Paradise. All the female characters believed they were outsiders in their own home because they had been isolated from their own family and friends; they also felt far away from the promises of freedom. They escaped from patriarchal society, and sought refuge in the delightful but temporary convent, which felt like home and where they could breathe freely in spite of their oppressions. In addition, 
Meyberry claims that male focus on physical beauty and romantic love made women feel uncomfortable in body and soul; consequently, these women had hoped for and got a perfect home of their own. Davidson (2012) in "Racial Stock and 8-Rocks: Communal Historiography in Toni Morrison's Paradise" focuses on the significance of reconstruction of community in Paradise and Morrison's beliefs in the role of narrative in the community. Davison states that the convent women are the protagonists and the community of Ruby as antagonist in this novel. He believes that Ruby is the main narrative, which focus on patriarchy and a superb collective historiography based on the submissive attitudes of individuals in the community. He also proclaims Paradise could be an extensive metaphor, an allegory of nationhood. Indeed, the convent women are the major focus of several studies. Krumholz (2012) in "Reading and Insight in Toni Morrison's Paradise" discusses the unstable combination of race and gender in the process of insight, which is comprehensible through the different aspects of history and ideology. She believes in Paradise the women are the image of innocence like Eve, and it is men's responsibility to prevent their exile from the Garden of Eden, which is earthly paradise in their minds. She continues to assert that the Ruby patriarch acts as if they are fully aware of God's will. She says that Morrison strives to create challenge in racial imagery with gender, class and sexual relations based on current black feminist theories. O'Reilly (1999) in "Maternal Resistance and Redemption in Toni Morrison's Paradise" tries to narrate Morrison's maternal philosophy in Paradise. She divides her article into three parts, first; she expounds Morrison' maternal theory, next she places this novel into this thematic framework and eventually, she explains how Paradise deals with Morrison's idea of motherhood and maternal redemption. She believes motherhood has a purpose, which is both political and public and black women are both nurturers and breadwinners. She states that mothering offers considerable healing which embraces all women in Paradise.

Many writers often depict the endless challenges that women face and the brutality of men in Paradise, but the problematic mother- daughter relationships are neglected in this novel. This article has endeavoured to present differing perspectives from others studies and uncover the unseen angles of motherhood through the mother-daughter relationships.

\section{Research Method}

The preparation of this paper has entailed careful reading and an accurate analysis of the elected fiction by Toni Morrison, because the study uses a qualitative research approach and thus it will discuss the mother-daughter relationship, the true meaning of which has been confused and overwhelmed by the overall dominance of patriarchy especially in the black community. The significance and extent of motherhood and how it assumes another identity under a male-dominated society; the effects of slavery and the economic situation of that era, are circumstances that have necessitated a profound understanding of what Morrison's stories wish to convey.

\section{Discussion}

The men of Ruby have endeavoured to create a secure place free of corruption by rejecting any form of discrimination and humiliation imposed by whites and/or fair skinned black people. They have sworn to protect their women but end up oppressing them. The male inhabitants describe their town as safe and free, where a woman can venture anywhere, anytime: "In, out, beyond the limits of town, because nothing at the edge thought she was prey "(Morrison, 1998: 9). 
The Disconnected Voices of Motherhood and Daughterhood in Toni Morrison's Paradise: Journey from Uncertainty to Chaos, Ahdiyeh Alipour, Zanyar Kareem Abdul

All of their attempts at constructing paradise are seen from their perspective: the women are like Eve who was expelled from the Garden of Eden. These men behave as if they know God's will, so their fear leads them to prevent this 'chaos' before their eyes. On the other hand, women have painted a picture of paradise that is free from male domination and rules. Morrison depicts two different views of paradise, where the people on the outside influence the lives of those on the inside. In one paradise, Ruby, the male dominated town is uniquely characterised. In the other paradise, there is the Convent, for females seeking refuge. In both Ruby and the Convent, the female characters are searching for selfidentity; both groups of women are searching for a sense of self that will permit them to feel free. The Convent is primarily female in this novel. It is a real paradise for helpless refugee women who have to deal with oppression, and represents a stage in their lives that empowers and gives them independence, away from the men of the city.

The oven in the city could also be a personification of women. Although built by men, the main purpose is to dominate women in their power. They constructed it to prevent women from working for the whites. Ironically, no one bakes bread in the oven since all of the townspeople buy their bread from the Convent. This act embodies an anomaly in the power of men over women, with women seemingly gaining power over men. This is then viewed by men as a threat to their manhood. The men of society, especially twin brothers Steward and Deacon, are the main leaders of oppression in the novel. To them, female domination must be suppressed in order to ensure their superiority and power over them, while also maintaining their perfect existence in town. These forlorn women however, commence their journey of self- discovery and find their voices thorough their relationships with their daughters. As Collins (1991) discusses in her book, Black Feminist Thought: Knowledge, Consciousness, and the Politics of Empowerment, the black woman's journey is unlike any other:

"The conceptualisation of self that is part of Black women's self-definition is distinctive. Self is not defined as the increased autonomy gained by separating oneself from others. Instead, self is found in the context of family and community. "(Morrison, 1998: 105)

She also describes the act of becoming a mother as:

"a significant step towards womanhood" (Morrison, 1998: 137). She also defines one perception of mothering: "Motherhood can serve as a site where Black women express and learn the power of self-definition, the importance of valuing and respecting ourselves, the necessity of selfreliance and independence, and a belief in Black women's empowerment". (Morrison, 1998: 118)

In Paradise, Toni Morrison explores the spirituality of motherhood, female society and its requirement in the Black woman's search for self. She uses the African American interpretation of 'maternal' and removes the social limitations placed on motherhood to bring a new concept to mothering. She endeavours to examine the image of motherhood, and challenges the traditional definition of mothering. Motherhood, in Morrison's view, is basically essential for black women in their fight against racism and sexism, and for their own self-worth. Motherhood empowers them to seek a better world for themselves and their children. All children are brought into the world with a hope and desire to see their growth into valuable human beings. Motherhood is a symbol of hopefulness. Value and 
empowerment result from the relationship between mother and child, especially mother and daughter. These values are inculcated by mothers, and simultaneously daughters confirm these values in their mothers. However, it is necessary to bear in mind that under the oppressive shadow of patriarchal rule, mother-daughter relationships can turn sour. The women in the Convent could be rejecting patriarchal society. As can be observed in the novel, most of the mother- daughter relationships are volatile because mothers, under the oppressive pressures of patriarchy, are unable to convey their true maternal love to their daughters.

A prominent example of this can be seen in the relationships between Delia and Patricia and between Patricia and Billie Delia. Delia, because of her fair skin and features, is said to have no name and no family, and is thus rejected in Ruby. Delia dies at childbirth because the men in the town were unwilling to assist her in getting medical care. Delia's sudden death then makes it impossible to inculcate in her daughter Patricia, the values and selfidentity that she will require to withstand oppression in this town. Patricia's lack of a mother's love and affection while growing up strongly affects her role as a mother. Patricia does not have any role model to follow in her relationship with her daughter, Billie Delia. Patricia, as an observer of all the cruelty in town is also considered an outsider: "Well, help me figure this place out. I know I'm an outsider, but I'm not an enemy.' 'No, you're not. But in this town those two words mean the same thing' "(Morrison, 1998: 212). However, she reveals the opposite image of motherhood than that of her own mother. As Collins (1991) points out: some women view motherhood as a truly burdensome condition that stifles their creativity, exploits their labour, and makes them partners in their own oppression" (Morrison, 1998:118).

Patricia could be under the umbrella of a notion of abjection, according to Julia Kristeva; abjection has been very practical in establishing a diagnosis of the domination of oppression. Matricide is our crucial essential because to become subjects through a male dominated culture, we have to abject the maternal body. However, women cannot abject the maternal body with which they are recognized as women, and can develop what Kristeva mentions as depressive sexuality. She advocates that on the stage of our individual psychosexual development, the abject is the time when we separated ourselves from the mother, when we start to achieve cognition towards a border between me and other, also between me and (m) other (McAfee 47). She writes a letter to her mother that shows she is still living in the past and eventually writes a letter to her mother. Her first act of motherhood appears at that moment when she burns all of her notes and papers for the genealogy project, as a means of catharsis for herself. It is only at this stage that Patricia frees herself; frees the memory of her mother and probably will have an opportunity to be a better mother for Billie Delia: "She felt clean. Perhaps that was why she began to laugh." (Morrison, 1998:217).

Billie Delia, her daughter, is essentially one of the most moral characters in Paradise. She is able to escape from all the inhumanity in Paradise. Her flight is made possible not by her own mother, but by others. They are not biological mothers, but provide the same nurturing that an ideal mother would provide her children. According to Kristeva, the maternal function cannot be reduced to the biological mother or women, and she suggests that to some extent, anyone has the ability to perform the maternal function, men or women. It means there is no obligation for a biological mother to apply the maternal role, for anyone in the family or community could take on a motherly role (Oliver, 2012). Indeed, Patricia strives to be a better mother but unconsciously the barrier still exists between her and her daughter. Dovey Morgan serves as an Other mother to Billie Delia. Billie Delia's 
The Disconnected Voices of Motherhood and Daughterhood in Toni Morrison's Paradise: Journey from Uncertainty to Chaos, Ahdiyeh Alipour, Zanyar Kareem Abdul

connection with her Other mothers has given her self-worth, and ultimately paves the way for her to escape the patriarchal town. Dovey's approval of Billie Delia is a cure for her loneliness since Dovey herself was controlled by her mother and the patriarchal society of Ruby. Considering her secret friend's age, Dovey can be thought of as a mother to her. Although she is always concerned about her husband and tries to be a good wife to him, Steward constantly spurns her attentions. In addition, being childless causes her much anguish and loneliness and it is all because of Steward. Dovey's mysterious friend is an enchanting distraction for this emotionally oppressed woman because Steward's silence as a husband creates a life devoid of meaningful chatter for her. Her true personality as a mother is revealed in her meeting with this friend who is twenty years younger. She goes beyond the expectations of patriarchal society. She speaks about everything which occupies her mind, as a mother would talk to her child, and she excels in the motherhood role, which gives her pleasure as well as freedom to express repressed emotions:

"Thing was, when he came, she talked nonsense. Things she did not know were on her mind. Pleasures, worries, things unrelated to the world's serious issues" (Morrison, 1998:92)

The repercussions of oppression can be observed in other mother-daughter relationship such as Seneca, Mavis, and Pallas. These women, who are exhausted from this discrimination and its effects on family, propels them to break all the rules and break out of their cages, and seek sanctuary in the Convent as their own paradise. Seneca is a shy woman who was abandoned by her fourteen-year-old sister, Jean, when she was just five years old. She is unable to speak about her innermost feelings because she grew up in a foster home and was sexually assaulted. Indeed, her sister is her mother, who was the victim of egotistical men, and due to her shame and fear of such a male dominated society, had to leave her child without any protector. Therefore, she has not had an opportunity to play the role of mother and create an emotional relationship with her child. This helpless girl without a mother as a guide is entrapped in a chain of abusive relationships: first, out of loneliness, she gets involved with another heartless man Eddie, who was in prison, and behaves inappropriately with her. Afterwards, there seems to be no other choice but to become a prostitute in Norma's house. All this unpleasantness and trauma causes her to seek a new identity and she comes to the Convent, which she sees as her new free world. At the end of the novel, her young mother looks for her to appease her own guilt, by the concise and short conversation, however again her stony-heart husband's rush does not let her to have a longer and deep conversation. Although this conversation is painful for her and the expression of regret dose not brings any reconciliation, there is some relief for them when Seneca says, "everyone makes mistakes" (Morrison, 1998: 317).

The expression of regret also exists for other mothers in this novel especially Dee Dee, who is the mother of Pallas. Pallas is a young girl, who has a bitter and troubled past. She is a child from a multiracial marriage. She lives apart from her mother, and has a poor and inappropriate relationship with her father, which leads her to become a needy, defenceless person. She starts a relationship with her school janitor, Carlos, who is much too old for her. This happens as a result of growing up in deprived surroundings. Possibly, she has thought that she found her prince and her fortunate; she abandons her father and drives off towards her mother. When they reach her mother's house, everything changes. Unfortunately, she comes to understand that Carlos and her mother are lovers. The loneliness of her mother affects her role of motherhood and certainly serving another man represents her as a victim. 
She has a profound sense of indignation towards these two people in her life. Eventually, she stumbles upon stability and prosperity in the Convent. When she temporarily leaves the Convent, she is raped by another abusive man. However, her self-worth and new identity, which she had obtained through life in the Convent assist her to overcome this trouble. The motherhood instinct of Dee Dee finally comes to the fore, so at the end of novel, she searches for her daughter and forgiveness. But the repercussions of betrayal by a tactless man only serve to put more distance between mother and daughter instead of reconciliation. The only mother and daughter who are able to bury the hatchet at the end of the story are Mavis and Sal. Mavis is an ordinary housewife who is hit by tragedy when her twins suffocate and die in a car. She not only has to endure this terrible crisis but also face a barrage of thoughtless questions from reporters and photographers. Her husband, Frank, and her daughter, Sal, do not seem to understand her grief, hence are not supportive; she alone has to bear the terrible burden of loss. This failed mother has attempted to please her love maker and achieves more attention toward herself, however the result is an opposite of her expectation, and brings shame to her life. Her behaviour obviously depicts her poor marital relationship with Frank. After her mistake movement, her abusive husband, instead of perceiving any angles of her deed and protecting her, he chooses silence. Frank communicates with others about everything but neglects her altogether. The coldness and unforgiving eyes of Sal, and her husband's indifference leads to fear and detachment, as they endeavour to hurt her (26). No one is trying to kill her, but the deep effect of that incident and her family's manner towards her, leads to paranoia. She has to bear the full responsibility of her children's deaths alone. Sal frequently hurts her mother in obvious ways under the shadow of her father's inconsiderate behaviour. There is no other option for Mavis but to leave and find a place where she can breathe freely; a place like the convent, which is non-judgmental, safe and comfortable. The Convent offers her a sense of stability and well-being and she begins to believe that her children exist with her and will grow up to be strong. In other words, she creates an intricate fantasy about the spirit of her contented children and this offers healing in her new life. At the end of her complicated story, she manages to put her past behind through a brief and emotional conversation with Sal. Finally, Sal seeks forgiveness albeit light-heartedly, and the process reinforces her motherhood role and completes her.

For her and the many other women, the dissimilarity between mother and daughter is blurred; there is no clear distinction between self-identity and motherly love. None of them have the ability to create any order out of their own emotional chaos. However, with Connie's aid as the mother of others, the women could support each other in their unique quest for an independent identity. In this novel, Connie plays the role of other mother for all these frustrated women. Connie's failure at love with Deacon, who prefers the patriarchal rules of his town over her, could be the turning point of her life and awakens something inside her. She decides to create an anti-male dominated strategy to change the lives of the suppressed women around her. Patriarchal power is a double-edged sword of oppression for these women in society. Eventually, the root of all these problems and difficulties in women's relationship with their daughters and others, lies in patriarchal society. Undeniably, the pressures of male domination in family and society create a kind of barrier, which unconsciously blocks the physical attention and maternal love between mothers and daughters. Furthermore, although women endeavour to be superb mothers, the shadow of patriarchal rule and its fanatical system prevent them from removing the barriers between 
The Disconnected Voices of Motherhood and Daughterhood in Toni Morrison's Paradise: Journey from Uncertainty to Chaos, Ahdiyeh Alipour, Zanyar Kareem Abdul

them; indeed, the abolishment of patriarchy could lead women to have fulfilling relationships not only with their daughters but also with others.

\section{Conclusion}

The primary sense of motherhood is love and positivity, and the primary experience of mother and child is ideally, the exchange of love between them. Indeed, the child has to be loved before she can love herself as a valuable and precious creature. A mother's relationship with her children and especially her daughters is the most powerful bond in the world albeit a fragile one. Toni Morrison strives to depict motherhood, which mirrors the social and cultural differences in society. She draws the image of motherhood within African American communities of the South and depicts the history of the south as well. She goes to show how all these factors affect motherhood for women without choices. It is apparent that the themes of motherhood and maternal love are invaluable to Morrison, and she strives to paint different facets of motherhood under the southern culture and social conventions.

The major feature, which most affects African American communities, is definitely that of class and race discrimination. Both men and women have borne the brunt of racial prejudice, but women have it worse because they experience humiliation and oppression from both black and white society. The role of black women as mothers under the heavy strain of pressure is an extremely complicated one and distinguishable from the rest of the women. To a black mother, sustaining and providing for her family take precedence over emotional expression. It is extremely difficult for a black mother to survive with tenacity under brutal oppressive rule and at the same time offer unwavering love and attention to her daughters. Black mothers' love, sacrifices and struggles for their daughters are often misconstrued as lack of maternal love and emotional attachment in their daughters' eyes. Chodorow (1978) argues:

"Black females are socialised by adult figures in early life to become strong, independent women, who because of precarious circumstances growing out of poverty and racism might have to eventually become heads of their own households. Black mothers teach their female offspring to perform adult tasks" (Chodorow, 13)

Unquestionably, lack of time and knowledge lead them to be cruel and cold mothers, in their daughters' eyes. The daughters scream to be heard, but their mothers do not hear them. The repercussions are anger and betrayal - strong emotions that the daughters feel towards their mothers. The mother-daughter relationship mirrors the emotional health and safety of these women and also their attitude towards other human beings. When a woman's emotional and social needs are fulfilled and they are treated right, their relationship with their daughters will also be loving and supportive. Conversely, a high level of conflict and negativity in a woman's life brings strain and turmoil to her relationship with her daughter; and these volatile mother-daughter relationships could be observed in communities, where women are treated like servants and not given an emotional outlet. Eventually, they learn to internalise their feelings and assume an uncaring persona. Daughters who come from these backgrounds aim to flee from their mothers, but the prevailing mother-daughter relationship, more often than not, causes them to replicate their mothers' behaviour. 


\section{References}

Adams, Alice. (1995). Maternal Bonds: Recent Literature on Mothering. Chicago: The University of Chicago: 414-427.Web. 30 May 2013.

Bakerman, Jane S. (2013). Failures of Love: Female Initiation in the Novels of Toni Morrison. JSTOR. American Literature 52 (1981): 541-563. Web. 29 Apr. 2013.

Chaney, Cassandra. (2011). The character of womanhood: How African American women's perceptions of womanhood influence marriage and motherhood. 512-53. https://journals.sagepub.com/doi/10.1177/1468796811415764.

Chodorow, Nancy. (1978). The Reproduction of Mothering: Psychoanalysis and the Sociology of Gender. Berkeley: University of California Press, Print. https://www.ucpress.edu/book/9780520221550/the-reproduction-of-mothering.

Collins, Patricia Hill. (1991). Black Feminist Thought: Knowledge, Consciousness, and the Politics of Empowerment. New York: Routledge, Print.

Davidson, Rob. (2001). Racial Stock and 8-Rocks: Communal Historiography in Toni Morrison's Paradise. Twentieth Century Literature 47 : 355-373. https://read.dukeupress.edu/twentieth-century-lit/articleZbstract/47/3/355/22367/Racial-Stock-and-8-Rocks-Communal-Historiography.

Krumholz, Linda J. (2002). Reading and Insight in Toni Morrison's Paradise. JSTOR. African American Review 36: 21-34. https://www.jstor.org/stable/i345958.

Mayberry, Susan Neal. Everything about Her Had Two Sides to It: The Foreigner's Home in Toni Morrison's Paradise." JSTOR. African American Review, 42 (2008): 565-578.

Morrison, Toni. (1998). Paradise. New York: Alfred A. Knopf, Print.

Oliver, Kelly. Kristeva and Feminism. Feminist Theory Website: Julia Kristeva. 1998.Web. 1 Nov. 2012. https://philpapers.org/rec/OLIJKF.

O'Reilly, Andrea. (1999). Maternal Resistance and Redemption in Toni Morrison's Paradise. Journal of the Association for Research on Mothering 1: 187-195. https://profiles.laps.yorku.ca/profiles/aoreilly/.

Ross, Ellen. (1995). New Thoughts on The Oldest Vocation: Mothers and Motherhood in Recent Feminist Scholarship. Chicago: The University of Chicago 20: 391-413. 